\title{
POLISH POLITICAL PARTIES TOWARDS THE CITIZEN LEGISLATIVE INITIATIVE
}

\begin{abstract}
Political parties are the key element of the representative formula of democratic system. The aim of the paper is to show parties' attitudes towards the citizen legislative initiative, being an institution of direct democracy. The analysis was carried out with the inclusion of the following three levels of party activity: conceptional, programme-related and functional. Both on the conceptional and programme-related levels there is a lack of reflexion and - in consequence hardly any debate held on the essence of the institution of citizen legislative initiative, its significance and consequences with regard to the socio-political system. This results in an almost mechanical acceptance of concrete legal solutions, which - at the next stage, i.e., that of realization of these records - ends in an escape from the problem (here: prolonging works of Parliament or an instrumental making use of citizens' activity).

Both ruling parties and those in the Opposition - despite obvious differences in the approach towards institutions of direct democracy - are joined by an axiologically justified dislike of strengthening these forms of citizens' engagement, which diminish the area of representative democracy.
\end{abstract}

\section{Key words}

Polish political parties; direct democracy; citizen legislative initiative

* Ewa Skrabacz, Department of Political Systems, Institute of Political Science, Opole University, Poland, skrabacz@gmail.com. 